\title{
Afet ve Aile İçi İlişkiler: Covid-19 Pandemisinin Aile İçi Tartışma ve Şiddet Üzerindeki Etkileri*
}

\author{
Disaster and Family Affairs: The Effect of Covid-19 Pandemic on Disputes between Family Members \\ and Domestic Violence
}

\section{Vehbi GÜNGÖR ${ }^{\mathrm{a}}$}

\section{Deniz ASKIN ${ }^{b}$}

${ }^{a}$ Acil Durum ve Afet Yönetimi Yüksek Lisans Öğrencisi, Bitlis Eren Üniversitesi, Bitlis/Türkiye, wehbigungor@gmail.com, ORCID: 0000-0002-7558-7921

b Dr Öğr. Üyesi, Bitlis Eren Üniversitesi, Bitlis/Türkiye, denizaskin13@gmail.com, ORCID: 0000-0003-0827-0534

\begin{abstract}
ÖZ
Bu çalışma Covid-19 pandemisi sürecinde aile içi ilişkilerde meydana gelen sosyal değişme, tartışma ve şiddet parametrelerini elde edilen nitel veriler üzerinden analiz etmektedir. Veriler doğrultusunda, bireylerin özellikle evde ve kapalı mekânda kalmalarından ötürü psikolojik sorunlar yaşadıkları ve bunun aile içi ilişskilere olumsuz bir șekilde yansıdığı görülmektedir. Bireylerin tartıșmalarını çoğunlukla "nedensiz" tanımlamasını, pandemi sürecinin zemin hazırladığı stres, kaygı, endişe gibi psikolojik durumların gündelik ilişkilere yansıması olarak değerlendirmek mümkündür. Çalışma kapsamında görüşülen kadın ve erkeklerin bu süreçten olumsuz etkilendiği görülürken, erkeklerin aile içi ilişkiler konusunda konuşmada daha isteksiz oldukları, buna karşın kadınların problemlerin arttığını ifade etmeleri de dikkat çekicidir. Saha çalışmasında, aile içi tartışmalara neden olan durumların çoğunlukla, evde kalınan süre içinde bütün davranışların gözetim altında olması, kadınların evde kalmaya başlayan erkekleri ev işlerine müdahale etmekle "suçlaması" iken bu durum çoğunlukla tartışma, bazen de şiddete varan sonuçlar ile aile içi ilişkileri olumsuz etkilediği çalışma bulgularına yansımaktadır. Çalışmada elde edilen veriler 2020 yılının Mart ve Nisan aylarında pandemiden dolayı sokağa çıkış yasaklarının uygulandığı süreçte 8 kadın ve 7 erkek olmak üzere toplamda 15 kişiye telefon ile ulaşılarak uygulanan yarı yapılandırılmış görüşme formuna dayanmaktadir.
\end{abstract}

Anahtar Kelimeler: Afet, Aile İçi İlişkiler, Covid-19, Aile İçi Şiddet.

\begin{abstract}
This study analyzes the parameters which have taken place during Covid-19 pandemic in the family relationships such as social change, arguments and domestic violence, with qualitative method. According to the data, people, especially because of the lockdown during the pandemic, have experienced negative psychological problems and that caused negative results on family affairs. It is possible to evaluate that the disputes identified "without cause" taken place between family members, especially parents, are due to stress, anxiety and concerns caused by pandemic process. The data of this study also shows that men and women have affected negatively from the process. However, it is interesting that despite the fact that men are more unwilling to speak about this negativity and family affairs, women argue that they have experience more problems than previous times. We have determined some reasons caused the disputes and problems among family members. Among them during the process of lockdown all family members had to stay at home and it brought about to keep a close watch on each other's behaviors; the women's accusing men to mess with housework are important among them. These situations mostly cause arguments, but sometimes led to violence among family members according to the data. The results of this study rely on the semistructured interviews conducted in March and April of 2020, the period when the curfew were imposed due to spread of Covid-19, with 15 people of whom 8 women and 7 men..
\end{abstract}

Keywords: Disaster, Family Affairs, Covid-19, Domestic Violence.

\footnotetext{
* Bu makalede bilimsel araştırma ve yayın etiği ilkelerine uyulmuştur. / In this article, the principles of scientific research and publication ethics were followed.
} 


\section{GíRiș}

Çin'in Hubey eyaletine bağlı Wuhan kentinde başlayan ve kısa zamanda tüm dünya ülkelerine yayılıp Dünya Sağlık Örgütü (WHO) tarafından pandemi olarak ilan edilen (11 Mart 2020) Covid-19, küresel ilişkilerin derin birlikteliğini görünür kılarken, aynı zamanda Beck'in (1992) ifadesi ile 'risk toplumu'nun yansımalarını ortaya koymaktadır. Zira bu durum, insanların/toplumların artık ürettikleri olumsuzluklardan bağımsız kal(a)mayacakları gibi, doğayı tahribatın sonuçlarına da küresel olarak katlanmak zorunda kaldıklarını göstermektedir. Afetin, küresel boyutuna karşın sosyal hayatın derinliklerine ve ilişkilerine de ciddi oranda etki ettiğini görmek mümkündür. Bu yönüyle gündelik hayatta genelden özele her alana etki eden Covid-19 pandemisinin aile içi ilişkilere de ciddi etkileri olduğu verilere yansımaktadır. Bu anlamda afet ve aile içi tartışma/şiddet arasında önemli oranda bir ilişkiden bahsetmek de mümkündür. Özellikle afet sürecinde ve sonrasında fiziksel ve ekonomik etkilerin yanında ölüm, stres, endişe, korku gibi psikolojik durumlar aile bireylerinin davranışlarını etkileyebilmekte ve hatta değiştirebilmektedir.

Günümüz toplumlarında insanların doğanın işleyişi üzerinde giderek daha fazla müdahalesinin artması neticesinde afetlerin sayısı ve bunun insan üzerinde bıraktığg etkiler artmaktadır (Gearhart vd., İnce, 2020a; 2017; Loayza vd., 2015; Philips vd., 2015). Bireysel olmanın ötesinde toplumsal ve günümüz Covid-19 pandemisi gibi küresel bir etki bırakan afetler, dünya ekonomisini, toplumsal hayatı ve uluslararası ilişkileri yeniden dizayn etmeyi gerektiren önemli bir kırılma noktasına işaret etmektedir. Tarihsel süreçte farklı yönleri ile deneyimlenen afetlerin tanımlarının da çeşitlendiğini ve bunun bırakılan etki doğrultusunda geliştiğini ifade etmek gerekir. Ancak bu değişkenliğe rağmen afetlerin inter disipliner bir tanımlamasının yapılması afet konusunun daha geniş bir zeminde tartışılmasını sağlayacaktır. Bu minvalde, Perry’in (2007: 6) ifade ettiği ve genel olarak üç farklı kategorideki tanımları birleştiren, afetin ortaya çıkardığ 1 "olumsuz-sıra dışı durumlar, can kayıpları ve sosyal hayatın sekteye uğraması" kavramları afetleri, sağlık, sosyal ve ekonomi zemininde tartışmaya açmaktadır. Bu doğrultuda tek bir disiplinin ele aldığı ve ilgilendiği alan itibariyle değil; daha geniş ve farklı tartışmalara imkan verecek şekilde bir tanımlamanın olması, gerek bu çalışma için gerekse de sonraki tartışmalar için önemli bir zemin sunmaktadır.

Afet sonuçları itibariyle, sadece afete maruz kalan ve birinci derecede ondan etkilenen kişilerin üzerinde değil, bununla beraber, duruma tanıklık edenlerde de bireysel ve toplumsal işleyişi ve sirkülasyonu etkilediği için genel bir etki alanı bırakmaktadır. Bu anlamda bireysel tartışmaların üzerinde afet, toplumdaki stres düzeyini, kaygıyı, intiharı da (Benedek vd., 2007: 56) arttırma riskini kendi içinde barındırmaktadır. Zira Covid-19 pandemisi de toplumda sadece hastalığa yakalan kişileri değil, bununla beraber kamu çalışanlarını, eğitim-öğretim faaliyetlerini, personellerini ve özellikle sağlık sektöründe çalışan kişilerin çok ciddi bir şekilde süreçten etkilenmesine neden olmuştur. Bu yönüyle, afeti onu deneyimleyen kişi ve kişilerin çok daha ötesinde toplumsal bir vaka ve olgu olarak değerlendirmek gerektiği ortadadır. Toplumsal tabakalaşmanın kısmen önemsiz kaldığı ve toplumun tüm kesimlerinin sağlığını/hayatını çok ciddi oranda etkileyen, sosyal ve psikolojik destekleri kesintiye uğratan Covid-19 pandemisi, afetlerin yeni çağdaş bir yüzü olarak ortaya çıkmaktadır. Zira daha önceki akademik çalışmalarda afet ve dezavantajlı gruplar arasında kurulan ilişkiyi (Dayton-Johnson, 2006: 7; Mustafa, 1998; Roth vd. 2017), Covid-19 pansemisi sürecinde de (İnce, 2020b) daha geniş bir şekilde düşünmeyi zorunlu kılmıştır.

\section{AFETLER VE AİLE İÇi İLIŞKILERE ETKİsi}

Covid-19 pandemisi sürecinde deneyimlenen önemli özelliklerinden birisi pandeminin aile üyelerinden şiddeti uygulayan ve şiddete maruz kalan bireyleri aynı mekânda kalmaya mecbur bırakmasıdır. Kurumsal işleyişin ve bu süreçte gerekli mercilere ulaşımın kısıtlanması, aile içindeki bilinmezliği arttırırken, bunun raporlanması ve sonuçlarını kesin verilerle ortaya koymanın henüz erken olduğunu da aktarmak gerekir. Covid-19 pandemisinin dikkat çeken diğer önemli özelliklerinden birisi de afet olgusunu ve sonuçlarını sosyal bilimler nezdinde incelenmeyi körüklemesi olarak görülebilir. Aynı mekânda kalmayı sosyal bilimler açısından ve özellikle sosyolojinin penceresinden değerlendirmek, içinde yaşadığımız toplumu anlama ve yorumlama açısından kayda değer veriler sunmaktadır. Evlilik ya da çeşitli nedenlerle aynı evde kalan kişilerden birinin hanedeki diğer kişilere yönelik şiddet içeren davranışı (Coulthard vd. 2020: 923) olarak tanımlanan aile içi şiddet, afet ve aileyi sosyolojik bir bakış ile incelemeyi hem önemli hem de gerekli kılmaktadır. Aile içi ilişkilerin geniş çerçevesi dikkate alındığında ise iletişimin kısıtlaması veya eksikliği, kontrol ve genel olarak ise kişinin 'kabul etmediği/edemeyeceği' şartlara maruz bırakılması olarak aktarılabilir. Stewart \& Robinson (1998: 83) ise aile içi şiddeti, aile içindeki bir bireyin beden bütünlüğünün, psikolojik durumunun veya özgürlüğünün güç kullanılarak tehlikeye atılması olarak tanımlamaktadır. Aynı şekilde aile içi şiddetin/tartışmaların/geçimsizliğin nedenleri olarak işsizlik, ekonomik yetersizlik, davranış(lar)ın kontrol edilmesi ve sosyal destek alınamaması afet dönemlerinde daha sık rastlandığı için, bu tür olağanüstü dönemlerde şiddetin arttığını gözlemlemek mümkündür. Nitekim afetin psikolojik etkisinin bireyi çevreleyen boyutu, kişinin hareket alanın kısıtlanması ve kayıpların artması aynı ortamı paylaşan kişilere yönelik şiddeti teşvik edebilmesidir. Bu durumda failin daha önce psikolojik destek alan bireyi bu tür bir hizmeti almasını engelleyebilmesi de (WHO, 2020) sosyal düzenin ve ilişkilerin geri gelmesi durumunda önemli toplumsal olgular ile karşılaşmamıza neden olacaktır.

Dünya genelinde afet sonrasında meydana gelen sonuçlar benzerlik göstermektedir. Toplumsal bunalım, ekonomik yetersizlik, stres, kaygı gibi durumlar kültür ve toplum fark etmeksizin afeti deneyimleyen insanlarda yaşanan temel sonuçlardır. Ancak Covid-19 pandemisi sonrasında meydana gelen gelişmelerde dünyanın daha önce deneyimlemediği bazı sonuçlar da yaşandı. Neredeyse tüm ülkelerde yerel veya ulusal düzeyde sokağa çıkma yasaklarının ve daha birçok üst düzey önlemlerin yaşandığı bir sürecin ortaya çıkması mevcut pandeminin önemli bir özelliği olarak kaydedilmektedir. Sokağa çık(a)mama durumunun kendi içinde meydana getirdiği parametrelerden biri de aile üyelerinin aynı mekânı paylaşmayı ve eldeki ekonomik imkanları dengeli kullanmayı zorunlu kılmasıdır. Ancak afetlerin meydana getirdiği psikolojik, sosyolojik ve ekonomik 
olumsuzlukların yanı sıra bireylerin ev içinde kalmak zorunda olmaları bazı olumsuzluklara da neden olabilmektedir. Şuan için güncel sonuçların yeterli oranda ortaya çıkmamasını da dikkate alarak aile içi tartışmaların ve şiddetin önemli bir oranda arttığını söylemek mümkündür. Bu anlamda Covid-19 pandemisi sürecinde Çin'de aile içi şiddetin normal oranın üç katına çıktığ1, Fransa'da bu oranın \%30, Brezilya' da \%40-50 oranında arttığı tahmin edilirken, İtalya ve İspanya gibi pandemiyi derin bir şekilde hisseden devletlerde aynı şekilde aile içi şiddetin arttığını gösteren veriler mevcuttur (Campbell, 2020:2). Covid-19 sonrası virüsün yayılmasını engellemek amacıyla alınan önlemler kapsamında bireylerin yakın ilişki içinde oldukları kişiler ile aynı mekanı paylaşmaları yukarıdaki verilerin en önemli nedenleri arasında gösterilmektedir. Özellikle kadınlara ya da genel olarak dezavantajlı gruplara yönelik şiddetin yakın kişilerden geldiği (WHO, 2020: 1) göz önüne alındığında mekânsal birlikteliğin sonuçları bu istatistikleri doğrulamaktadır. Nitekim henüz ülkelerin güncel verilerini kamu ile paylaşmamalarına rağmen, pandemiyi toplumsal olarak hisseden ülkelerden İngiltere, ABD ve Çin'den gelen bilgilerin de aile içi şiddet ihbarlarında ve oranlarında önemli bir artış olduğunu göstermektedir. Bu bağlamda ABD'de pandeminin ilk dönemlerinde (Mart, 2020) kadınların evde durmak zorunda kaldığı/bırakıldığı ve koronavirüse yakalanmaları durumunda dışarıda kalacakları yönünde tehditler aldıkları, sosyal ilişkilerinin kısıtlandığı ve tehditlerin çoğaldığı verilere yansımaktadır (Godin, 2020). Benzer şekilde Çin'in Hubei eyaletinde bulunan Jingzhou kentinde, aile içi şiddet raporlarında 2019 yılının Mart ayına göre üç kat daha fazla olduğu kayıtlarla sabittir (Allen-Ebrahimian, 2020).

Yukarıda ifade edildiği üzere pandeminin halen sürüyor olması ve bunun yeni çalışmalara imkân vermemesi, kurumsal işleyişin normal seyrine dönmemesi ve henüz verilerin paylaşılmaması net sonuçları ortaya koymayı önlemektedir. Sadece eldeki bu kısıtlı veriler değerlendirildiğinde aile içi şiddetin arttığı ve görünenin, görünmeyen kısmın çok az bir oranını oluşturduğu izlenimine neden olmaktadır (Campell, 2020: 2). Bu öngörü ortaya konulurken toplumsal hafızayı yoklamak yerinde olacaktır. Nitekim dünya genelinde afet ve olumsuz davranış kalıplarının ortaya çıkma durumu arasında önemli bir ilişki bulunduğu daha önceki çalışmalarla mevcuttur. Bireylerin meydana gelen afetten etkilenme derecelerine bağlı olarak, bu etkiyi sosyal hayata yansıtma durumu neden-sonuç ilişkisi içinde farklı ülkeler için benzer sonuçlar ortaya çıkarmaktadır. Örneğin ABD'deki Washington, Skamania'nın St. Helens Dağı'nda meydana gelen patlamalar neticesinde Othello'da aile içi şiddet oranlarında \%46 oranında bir artış meydana geldiği kaydedilmektedir. Ancak sonuca işaret eden bu verinin arka planına bakıldığında olayı deneyimleyen ve sosyal hayatı etkilenen kişilerde, stres, saldırgan davranışlar, alkol kullanımı, psikolojik bunalımların ciddi oranda arttığı görülmektedir. Kendi içerisinde nedeni oluşturan bu tür durumların sonuca yansıması ile sosyal ve toplumsal bağlamda önemli sorunlar ortaya çıkmaktadır (Adams \& Adams, 1984: 256). Buna paralel olarak, Tayvan depremi ve Floyd Kasırgası sonrasında sosyal ilişkilerde şiddetin arttığını (Keenan, 2004), Bangladeş’teki selin ardından benzer sonuçlar doğrultusunda gerek ev içi gerekse de bireyler arası şiddetin arttığı görülmektedir (Biswas vd. 2015). Bununla beraber, Katrina Kasırgası sonrasında özellikle kadınlara yönelik suiistimal ve taciz olaylarının \%35 oranında artığı rapor edilmektedir (Schumacher vd., 2010: 593). Güney Florida'daki Andrew kasırgası sonrasında aile içi şiddete yönelik ihbarlarda \%50 oranında bir artış meydana geldiği de aktarılmaktadır. Bu bağlamda zorunlu olarak evde kalan, sosyal ilişkilerinde kısıtlama yaşayan, yakınlarından birinin kaybedilmesi ve ekonomik olarak alınan hasar bireylerin aile içi durumlarını daha önce görülmeyen şekilde etkileyebildiğini de vurgulamak gerekir (Gearhart, 2017: 2).

Türkiye'de 1999 Marmara depreminin ardından yaşanan olaylar benzer şekilde toplumsal travmanın arttığını, bireylerin şiddete ve intihara daha meyilli olduğunu göstermektedir (Vehid vd., 2006). Türkiye'de bu alanda yapılan çalışmaların azlığının ve öneminin farkında olarak, kapalı bir toplum ve aile içi ilişkilerin mahremiyet çerçevesinde değerlendirilmesi de bu tür durumların görünürlüğünü azaltmaktadır. Bununla beraber, Türkiye’de bu konu üzerine yapılan çalışmaların çoğunlukla istatistiksel ve dışarıdan bir gözle analize odaklanması, nitel çalışmalarla ortaya çıkabilecek olgunun derin bilgisine varmanın önemini arttırmaktadır. Bu anlamda Sabuncuoğlu vd., (2003), Tanhan \& Kardaş (2014), Kurt ve Gülbahçe (2019) gibi çalışmalar Türkiye'de afetin daha çok sağlık bilimleri ekseninde ele alındığını ve verilerin bu yönde incelenmeye çalışıldığını göstermektedir. Ancak Türkiye'de afetlerin olası sonuçları düşünüldüğünde bunun bir bakıma haklılık payı olmakla beraber bireysel ve toplumsal anlamda kişilerde meydana getirdiği davranış değişiklikleri ve bunun sosyolojik verilere yansıması da kesinlikli göz ardı edilecek bir durum değildir.

Pandemi öncesinde sahada faal olarak çalışan kurum ve kuruluşların pandemi sürecinde bu yöndeki faaliyetlerinden "kısmen"de olsa uzak kalması da aile içinde yaşanan durumların bilinmezliğini arttırdığını söylemek mümkündür. Zira aynı ve kapalı bir mekanı kullanan aile bireylerinde şiddeti uygulayan kişiler, şiddete maruz kalanların günümüz iletişim teknolojilerine dahi erişimini kısıtlayabilmekte ve bu noktada gerekli mercilerin durumdan haberdar edilmesi engellenebilmektedir. Bu anlamda, pandeminin toplumsal dolaşımı kısıtlaması, aile bireylerinin dış dünya ile irtibatını ve bilgi alış verişini kısıtlarken, şiddet uygulayan kişi(ler), şiddete maruz bıraktıklarının dış dünya ile iletişiminini kesebilmektedir (NDVH, 2020; Campbell, 2020: 1). Zira verilere yönelik yapılan çalışmada mağdurların ihbar için, şiddet uygulayanın olay mahallinden ayrılmasını beklemek durumunda kaldığ1 görülmektedir. Covid-19 pademisi döneminde evde kalma süresinin uzaması ve mağdur ile şiddeti uygulayanın aynı ortamda bulunması şiddet oranını ve sıklığını etkileyebilmektedir. Bu bağlamda yapılan çalışmada şiddet durumlarında polise gelen ihbarların büyük bir kısmı mağdur kişi tarafından yapıldığı görülmektedir. Diğer önemli bir veri ise çok küçük bir kısmının (\%7) ise polisin eve gitmesi durumunda failin evde olduğu rapor edilmektedir. Zira mağdur kişi, kendisine şiddet uygulayan kişi evde iken çoğunlukla ihbarda bulunamamaktadır. Aile içi şiddetin faillerinin genel tablosuna bakıldığında bu kapsamdaki bireylerin daha önce benzer durumları sergilediği, mağdurların \%87 oranında kadınların, şiddet suçlusu olarak da erkeklerin olduğu görülmektedir (Campbell vd., 2017: 7-14). Nitekim dezavantajlı ya da şiddete maruz kalan kişinin iletişim kanallarına ulaşması kendi içerisinde bazı engelleri barındırırken, aynı zamanda şiddet uygulayan kişinin de buna 
izin vermeme durumu yüksektir. Covid-19 verileri ve deneyimleri üzerinden bu durum analiz edildiğinde önemli sonuçlar elde edilecektir.

Sokağa çıkma yasağının olduğu dönemlerde şiddet olayının olması durumunda, şiddeti uygulayan kişinin evden çık(a)maması, ihbarların/raporların oranını ciddi oranda düşürmesi beklenebilir. Buradan çıkarılacak sonuca bakıldığında şiddete maruz kalan kişinin/kişilerin, fail evde olduğu sürece yardım alması daha zor olmaktadır. Nitekim failin iletişim imkânlarını kısıtlaması, bireyi belli bir mekâna hapsetmesi ve bu süreçte fiziksel ya da psikolojik şiddetin miktarını ve sıklığını arttırması da ihtimal dâhilindedir (Gearhart, 2017: 2). Bu duruma paralel olarak sağlık kurumlarının da önemli işlevlerinden biri saldırıya maruz kalan aile üyelerinin tespiti olarak görülebilir. Zira şiddet gördüğü halde bunu yetkili birimlere rapor etmeyen/edemeyen kişilerin tedavi için hastaneye gitmeleri durumunda sonuçlar görünür olabilmektedir. İngiltere'de yapılan çalışmada şiddete uğrayanların \%94,4 gibi çok büyük bir kısmı darbeyi baş bölgesine aldığı verisi paylaşılmaktadır (Ochs vd., 1996). Bu durumda özellikle sağlık sektöründeki bazı uzmanlıkların bu tür durumlar ile karşılaşmaları ve bunu rapor etmeleri önemli iken Covid-19 pandemisi sürecinde erişimin kısıtlanması ve hastanelerin sadece acil durumlarda hizmet vermesi yeni verileri ortaya koymayı engellemektedir. Özellikle aile içi tartışma/şiddet durumlarında yukarıda ifade edildiği üzere hasar alan baş bölgesi ile ilgilenen dişçi ve cerrahi uzmanlıkların bu tür durumları yetkili birimlere bildirmesi sonraki, daha ağır vakaları da önleyebilmektedir (Coulthard vd., 2020: 923). İhbar oranlarının düşmesi ile beraber sağlık personellerinin vakayı yetkili mercilere bildirememe durumları dikkate alındığında şuan için elde edilecek verilerin doğruluğu noktasında zamana ihtiyaç olduğunu söylemek gerekir. Godin'e (2020) göre, pandemi sonrasında şiddete maruz kalan kişilerin -çoğunlukla kadınlar- pandemi sürecinde yeterli düzeyde yardım almayacaklarını düşünmeleri, sağlık ve psikolojik destek merkezlerinin/hizmetlerinin faaliyetlerinin kısıtlanması ya da kapatılması da onların ihbarlarını önleyebilmektedir.

\section{AFETLERIN TOPLUMSAL YÜZLERİ VE YENİ EĞIILIMLER}

Afet dönemleri özelde bireylerin ama genelde toplumların dolaşımını ve erişimini kısıtlamasından dolayı bir enerji birikimi ve stresi beraberinde getirmektedir. Stresin şiddete evirilmesi ve dezavantajlı gruplara yansıması çok ciddi sonuçları doğurabilmektedir. Bu bağlamda Rezaeian'a (2013: 1105) göre afet sonrası dönemde bu olası şiddet risklerini önlemek için şiddeti sergileyen ve şiddete açık grupları birbirinden ayırmak gerekebilir. $\mathrm{Bu}$ süreçte dezavantajlı grupların ihtiyaçları belirlenmeli ve bu doğrultuda gerektiğinde devlet koruması sağlanmalı ve sağlık hizmetleri yeterli ve uygun bir şekilde sunulmalidir.

Pandemiden dolayı evde kalış süresinin uzaması, beraber zaman tüketiminin artması ve daha öncede vurgulanan kapalı mekanın bireyin psikolojisini olumsuz yönde etkileme durumu, aile içi şiddeti ebeveynler ya da yetişkinlerin ötesine taşımaktadır. Bu şekilde özellikle çocukların ve ailede kalan diğer canlıların (evcil hayvanlar) dahi olaydan etkilendiğini ve onların çoğunlukla pasif kurban oldukları görülmektedir. Özellikle çocukların daha fazla kontrol altında tutulmak istenmesi, hareketlerin izlenmesi ve ödevlerin/sorumlulukların artması önemli olumsuz sonuçların yaşanmasına neden olabilmektedir (Campbell, 2020, 2). Ayrıca çocukların okula gitmemesi ile dış gözlemcilerden (öğretmen, doktor vb) uzak kalması onların hane içinde yaşanılan durumları kabullenmesine neden olduğunu da vurgulamak gerekir (Coulthard vd., 2020: 923). Aile içi şiddetin genel olarak kurbanı konumunda olan çocukların kendilerinin deneyimledikleri olumsuzluklarının yanında aile içinde ebeveynlerin stres ve kaygılarını yansıttıkları birer hedef olmaları bazı durumlarda şiddet ve ölümcül olabilecek sonuçların yaşanmasına da neden olabilmektedir. Bu noktada Keennan ve diğerlerinin (2004) ve Liem \& Reichelmann (2014: 2) yaptıkları çalışmada çocukların bu dönemlerde daha fazla şiddete ve baskıya maruz kaldığını ortaya koymaktadırlar. Gündelik hayatta dezavantajlı konumda olan çocukların ebeveynlerle aynı süreci deneyimlemeleri ve bunu kendi dünyalarında anlamlandırma güçlüğüne ek olarak, aile büyüklerinden de tekrardan baskı ve şiddet görmeleri onların psikolojik ve fiziksel olarak zarar görmelerine yol açmaktadır. Ancak dezavantajlı gruplardan biri olarak çocuklar ile ilgili verilerin kısıtlı olması, pandemi sürecinde ihbarların ve raporların önemli oranda düşmesine neden olurken bunun sonucunun çocukların ev dışına çıktıktan sonra belirginlik kazanacağını söylemek mümkündür. Zira çocukların okula başlaması ve evde kaldıkları süreçte yaşadıklarını rapor etmesi/bildirmesi ile bilinebilecek olması onları, ev içindeki anne-baba şiddetinin görünürlüğünden ayırmaktadır. Çünkü bu süreçte çocukların da evdeki diğer kişiler tarafından olumsuz durumlara maruz bırakılabileceğini ancak bunun görünürlüğünün şuan için kısıtlı olduğunu aktarmak gerekir (Campbell, 2020: 2). Bu süreçte önemli bir tecrübe göstergesi olarak, İngiliz hükümeti evde kalması durumunda şiddete uğrayabilecek kişilere yönelik evde kalma/izolasyon uygulamaması önemli bir deneyim göstergesidir (Coulthard vd., 2020: 923). Bu durum daha önceki örneklerden ya da vakalardan elde edilen veriler doğrultusunda uygulanırken, evde kalma ve sokağa çıkamama durumunda yaşanabilecek stres, kaygı ve sosyo-psikolojik sorunların olumsuz bir sonuca neden olmasının önüne geçilmeye çalışıldığını göstermektedir.

Pandemi sürecinde yaşanan sosyal yalıtılmışlık ve ekonomik sıkıntılardan dolayı stres artarken (Benedek vd., 2007) bunun aile içinde cinayete varan durumlara zemin hazırlaması da muhtemel bir risk olarak görülebilir. Zira şuan için Türkiye'de pandemi sonrasında veya sürecinde silah satışları ile ilgili bilgiler yer almazken, özellikle Amerika'daki veriler dikkate alındığında (NPR, 2020) ateşli silaha ulaşma ve bunun cinayete varma durumu arasında çok yakın bir ilişkinin olduğu görülmektedir. Bunu destekleyen bir veri olarak, ABD’de Pandemi sürecinde ateşli silah satışlarında ciddi artışlar göstermesi aile içi tartışmaların öldürme-ölümle sonuçlanma riskini arttırmaktadır. Silah satışları ve öldürme arasındaki korelasyonun ortaya koyduğu sonuçlarda, bireylerin silaha erişimi ve sonuç olarak ölme-öldürme durumları artarken (Liem \& Reichelmann, 2014) bunun toplumsal yansımaları ve bazı durumlarda savunma amaçlı yeni bir dalgayı da tetikleyebilmektedir.

Afet sonrası süreçte yakın akrabaların veya kişilerin kaybedilmesi de bireysel ölçekte davranış değişikliğini doğurmakta ve yine mikro ölçekte olumsuz sonuçlar doğurabilmektedir. Bu anlamda en sık görülen bir davranış olarak intihara eğilim ya da 
kendine zarar verme de afet sonrası süreçte meydana gelebilecek durumlar arasında gösterilebilir (Vehid vd., 2006: 20). Bu yönüyle afet sonrasında toplumsal bir varlık olarak bireyin deneyimlediği önemli olumsuzluklardan biri olarak stres, kişiyi psikolojik destek almak zorunda bırakabilmektedir. Ancak Covid-19 pandemisi sürecinde yaşanan sokağa çıkma yasakları ve sosyal ilişkilerin kısıtlanması bireyleri daha önce belli ölçülerde rehabilite ettikleri bu durumlarıyla baş başa bırakmıştır. Özellikle afet öncesi süreçte sosyal ve psikolojik destek alan kişilerin bu durumlardan daha fazla etkilendiğini ifade etmek gerekir (Kanaisty \& Norris, 1995: 95). Afetin gündelik ilişkilere yansıması ve bunun toplumsal olarak ortaya çıkardığı yeni boyutlardan birisi de şiddetin kronikleşmesidir. Bu yönüyle aile içi ilişkileri olumsuz etkileyen afetlerin bıraktığ 1 etkileri toplumsal olarak deneyimlerken, bu alışkanlıkların geleceğe aktarılması ciddi bir riske işaret etmektedir. Bu minvalde Fisher'in (2010) Tsunami sonrasında Sri Lanka'daki aile içi şiddet vakalarını konu alan çalışmasında, afet ve aile içi şiddet arasında önemli bir ilişki bulunduğu vurgulanmaktadır. Ancak çalışmayı önemli kılan diğer bir veri ise, afet öncesinde aile içi şiddet durumları yaşanmayan hane halklarının afet sonrasında bunu deneyimledikten sonra şiddetin artık sıradanlaşması ve aile içi ilişkilere yerleşmesidir. Bununla beraber çalışma bulgularında daha öncesinden aile içinde nadir görülen şiddet olaylarının afet sonrasında önemli oranda arttığ 1 da kaydedilmektedir.

\section{ARAŞTIRMANIN METODU}

$\mathrm{Bu}$ çalışma, pandemi sürecinde kapalı ve toplumsal olarak "mahrem" kabul edilen aile içi ilişkilerde meydana gelen şiddeti/tartışmayı genel bir olgu olarak ele almaktadır. Bu minvalde, mahremiyet ilişkilerinin ve anlayışının dışarıya bilgi akışını kısıtlamasından dolayı, herhangi bir cinsiyet grubunu hedef almanın önüne geçilecek, ayrıca Türk toplumunun aile noktasında mahremiyet gerçekliğine dikkat çekilecektir. Zira saha çalışması süresince gerek kadınlarla gerekse de erkeklerle yapılan görüşmelerde, pandemi sürecinde aile içinde şiddet durumları olup olmadığı sorusu genel olarak "tartışmalar oluyor" ifadesi ile karşılık bulmuştur. Meydana gelen “tartışma”nın detaylandırılması istendiğinde ise katılımcıların bu yönde konuşmak istememeleri dikkat çekmektedir. Türk aile yapısı üzerine yapılan çalışmalar, ailenin kapalı bir alan olarak algılanması ve bazı durumlarda eşler arasında mahremiyetin sağlan(a)maması durumlarında da boşanmaların yaşandığını göstermektedir (Özkiraz \& İşçi Baş, 2016: 93). Dinsel olarak da desteklenen aile mahremiyetinin dişarı aktarılmaması ve ailevi ilişkilerin eşler arasında kalması yönünde bir inancın hâkim olduğu Türkiye'deki toplum yapısı da (K1lıç, 2018) aileyi özel bir alan olarak kabul etmektedir. Bu durum aile içinde meydana gelen bazı olumsuz durumları bilmeyi zorlaştırmaktadır. Ancak saha çalışmasında karşılaşılan bu sınırlılık, görüşmelere hanedeki diğer bireylerin katılımı sağlanarak aşma yoluna gidilmiştir.

Çalışma nitel olup veriler, uygun (convenience) örneklem metodu ile İstanbul, Ankara ve İzmir'de ikamet eden toplamda 15 kişi $^{1}$ ile telefon üzerinden yapılan görüşmelere dayanmaktır. Çalışmanın bu üç il eksenli yürütülmesinin temel nedeni bu illerde sokağa çıkma uygulamasının uzun sürmesidir. Örneklemler farklı kategorilerden seçilerek çalışmanın tek bir yaş ve cinsiyet grubuna indirgenmesi önlenmiş ve yukarıda da tartışıldığı üzere şiddete maruz kalan, uygulayan ve bazen de şahit olan gruplara ulaşılması hedeflenmiştir. Zira saha çalışması sürecinde görüşme yapılan ebeveynler dışında evdeki diğer kişilerin/çocukların ebeveynleri arasındaki tartışmaları aktarması bu çalışma için önemli bir veri kaynağı olarak görülmektedir. $\mathrm{Bu}$ bağlamda çalışma sadece şiddete uğrayan veya fail ekseninde bir çalışma olmaktan ziyade üçüncü bir gözlemci kişi ile duruma farklı bir pencereden bakma fırsatı sunmaktadır. Bununla beraber emekli, öğretmen, öğrenci, ev kadını ve çalışan olmak üzere farklı iş kollarından kişiler çalışmaya dâhil edilerek dışarıdan gözlem ve aile içi tartışmaların/şiddetin etkisi ve pandeminin neden olduğu kayg1, stres, endişe gibi durumların geniş bir ölçekte analizi hedeflenmiştir. Ancak çalışma, elde edilen verileri genelleme iddiasında bulunmazken, bulgular pandemi döneminde yaşanan aile içi ilişkileri sınırlı katılımcı sayısı üzerinden ortaya koymayı amaçlamaktadır. Çalışma Bitlis Eren Üniversitesi Etik İlkeleri ve Etik Kurulunun 22/12/2020 tarih ve 2020/12XI sayılı kararlarıyla da uygun görülmüştür.

Afet ile aile içi tartışma/şiddet arasında sıkı bir ilişkiden bahsetmek mümkün olsa da, bu olgunun bazı nedenlerden dolayı tam olarak anlaşılması engellenmektedir. Bunun temelde iki nedeni bulunmaktadır. Birinci olarak, ihbar ve raporlama durumlarında yaşanan aksaklıklardır. Özellikle afet sürecinde ailenin içe kapanması, dış irtibatın ve iletişim imkanlarının kısıtlanması bu tür verilere ulaşmanın önemli sınırlılıklarından birini oluşturmaktadır. İkinci olarak, afet sürecinde/sonrasında kısa dönemde yaşanan şiddet olaylarının belli bir süre geçmesi ile beraber aile üyelerinin yaşananları dönemsel değerlendirmesi ve rapor etmeye değer görmemesidir. Bu çalışmanın da aynı sınırlılıklara sahip olduğunu vurgulamakla beraber Türkiye ölçeğinde düşünüldüğünde aile içi mahremiyet durumunun gerçekliği ile beraber yaşananların saha çalışması sürecinde aktarılmama durumu da bu tür çalışmalarda üzerinde düşünülmesi gereken önemli bir ayrıntıdır.

Nitel araştırmaların bir olay ya da olgu karşısında kişinin deneyimlediğine odaklanması ve bunu özel olarak kabul etmesi saha çalışmasından elde edilen verilerin özgün olmasını sağlamaktadır. Zira nitel araştırma, gerçekliğin inşa edildiğini kabul ederken, bireysel deneyimleri ve toplumsal bağlamı da önemli görmektedir (Neuman, 2006: 132). Keşfedici bir model ile yapılan bu nitel araştırmada araştırmacı ailenin korunaklı ve kapalı yapısını gözeterek aile içi şiddet/tartışma konuları ile ilgili genel düzeyde bir bilgi toplanmaya çalışmıştır. Gerek pandemi sürecinde bireylerin evde kalma gerekse de fiziksel temasın riskli olduğu bu süreçte yüz yüze görüşmenin mümkün olmaması konunun yeni bir deneyim kapsamında ilerlediğine işaret etmesi açısından da önemlidir. Bu realite örneklem seçim yöntemini de belirleyerek daha detaylı bilgilerin elde edilmesi adına uygun örneklem metodunun kullanılmasını gerektirmiştir. Bu minvalde hazırlanan görüşme soruları, evde kalmanın zorunlu olduğu 2020 yılının Mart ve Nisan aylarında bireylere telefon ile ulaşılarak yarı yapılandırılmış derinlemesine görüşme formu uygulanmıştır.

\footnotetext{
${ }^{1}$ Çalışmaya dâhil olan katılımcılaırn istekleri üzerine gerçek isimleri kullanılmamıştır.
} 


\section{BULGULAR VE YORUM}

\subsection{Aile İçinde "Nedensiz" Tartışmalar Ya Da İlişsilerin Değișen Formları}

Covid-19 pandemisinin "artık hiçbir şey eskisi gibi olmayacak" mottosu toplumsal hayatta somut bir karşılık bulurken bunun aile içi ilişkilere nasıl yansıdığı, eşlerin birbirlerine davranış tarzlarında ne tür değişikliklere neden olduğu henüz tam anlamıyla ortaya konmuş değildir. Türk toplumu açısından mahrem olarak kabul edilen aile içinde evde kalma, stres, kaygı, geleceğe yönelik bilinmezlik, ekonomik endişe gibi durumların yaşanması yeni tartışma alanlarını doğurmaktadır. WHO'nun Covid-19 pandemisi sürecinde stresten kaçınmak için sunduğu önemli önerilerden biri de "çok fazla haber izlememe ve güvenilir kaynak kullanılması" iken, saha çalışması sürecinde örneklemlerin neredeyse tamamı bu dönemde çok daha fazla ve sıklıkla televizyon ya da genel olarak haberleri takip ettiklerini bildirmeleri dikkat çekicidir. Zira bazı katılımcıların, günün ortalama 9-10 saatini haber izleme ve/veya takip etme ile geçirdiğini ya da "televizyon her zaman açık" beyanları stres kaygı ve endişenin daha fazla artmasına ve bunun yansıması olarak aile içi tartışma ve bazen de fiziksel şiddete dahi neden olabilmektedir. Yukarıda tartışıldığı üzere dünya genelinde 2020 Ocak ayından, 2020 Mayıs ayı sonlarına kadar aile içi şiddet ve boşanma oranlarında önemli bir artışın olduğu görülmektedir. Ancak virüs tehlikesinin henüz tam olarak geçmemesi, eşlerin yaşanan sorunları ötelemesine neden olması kesin verilere erişimi engellemektedir. Saha çalışması sürecinde kadın ve erkeklerin ev içi sorunlar hakkında farklı tutumlar sergiledikleri görülürken, sorunların dışarı aktarılması noktasında da erkeklerin kadınlara kıyasla daha ketum bir görüntü sunmaları dikkat çekicidir. Özellikle erkeklerin aile içi problemleri genel olarak "tartışma” başlığı altında ifade ettikleri, bunu mahremiyet noktasında değerlendirdiklerini söylemek mümkündür. Zira saha çalışması sürecinde yapılan görüşmelerde bireyi arama, konuşma ve kendisinin tereddütlerinden bu durumu anlamak mümkündür. Erkekler tarafından aile içinde uyumsuzluk sorunlarının, tartışmaların yaşanıp yaşanmadığı yönündeki sorular çoğunlukla kısa bir tereddütten sonra cevaplandığı ve genel olarak sorunu kendisinden dişsallaştırdığ́1 ve ötekileştirdiği görülmektedir. Örneğin Kerem'e, (32 Yaşında, Erkek) evde kaldığı süreçte aile içinde sorunların yaşanıp yaşanmadığı sorusu sorulduğunda kısa bir tereddütten sonra "Yakın çevremde bu sıkıntıları yaşayanlar çok oldu. Ama bizde yok" Bu cevabın üzerine ne tür sıkıntılar yaşandığını duydunuz? Diye sorulduğunda ise soru cevapsız kaldı. Aynı şekilde bu soru katılımcılardan İlhami’ ye (40 yaşında, erkek) yöneltildiğinde "Yok ailecek iyiyiz". Umut'un (40 yaşında, erkek) "farklı bir şey yok eskisi gibiyiz", İsmet'in (60 yaşında, erkek) bu soruya sadece "yok" deyip daha fazla yorum yapmayıp konuşmak istememesi tarzında Kerem'in cevabına yakın bir karşılık vermesi erkeklerin bu süreci ve evde yaşanan durumları dışarıya yansıtma noktasında benzer tutumlar sergilediklerini göstermektedir. Bu konuda kısmen de olsa soruyu cevaplayan Sabır (62 yaşında, erkek) bu süreçte yaşanan durumu şu şekilde açıklamaktadır. "Fazla bir sorunumuz olmadı ama hanım fazla evde kaldı̆̆ için bazen sıkıntılarımız oluyor. Tabi şiddet boyutu olmaz ama genel olarak insan sıkıldığ için tartışma oluyor." Ve benzer bir şekilde “ Serdar (36 yaşında, erkek) "“"eşimle daha fazla zaman geçirmeye başladıktan sonra oldu. Yaşamın bütün alanında birlikte vakit geçirdiğin için bazı noktalarda uyumsuzluklar başladı tabi”. Bu tür durumlar söz konusu görüşme yapılan kişilerin şiddet uyguladığı anlamında değil, daha çok bu alanı mahremiyet çerçevesinde ele aldıklarının bir göstergesi olarak değerlendirmek de mümkündür. Aynı mekânı paylaşma noktasında ve davranışların gözetim altına alınması doğal olarak bazı sorunları doğurmaktadır. Ancak aile içi ilişkilerin değişmesi ve tartışma konusuna dönüşmesi bu sürecin farklı bir boyutuna göndermede bulunmaktadır. Bu konuda Yücel'in (48 yaşında, erkek) deneyimine bakıldığında "Tabi yaşıyoruz. Örneğin ufak bir sıkıntıda uyumsuzluk yaşıyoruz. Sürekli evde kaldığımız için ve sıkıldı ğınız için ister istemez bu diğerlerine yansıyor. Bă̆ırma çă̆ırma şeklinde geçiriyoruz. Bu süreçte bu sıkıntılar baş gösterdi diyebilirim. Bunun sadece bizimle sınırlı olmadığını söylemek isterim. Kaldığımız binada da bağırmalar çă̆ırmalar olmuyor değil, kavga gürültü eksik olmuyor." Bu konuda en açık ve konuyu kapatmak yerine konuşmayı tercih eden Yücel, aile içinde problemlerin yaşandığını ifade ettikten sonra "bunun kendileri ile sınırlı olmadığını" aktarması da önemli bir veri olarak karşımıza çıkmaktadır. Çünkü sorunun genel olduğu ve verdiği cevap ile kendisinin hedef gösterilmesine yönelik tereddüt yaşadığını anlamak mümkündür.

Ancak burada farklı bir bakış açısı ile de durum analizi yapmak gerekir. Nitekim aile içi şiddet tartışmalarında failin çok büyük oranda erkek, mağdurun ise kadın olması verilerin aktarılma(ma) durumunun belirleyici bir nedeni olabilmektedir. Verilere göre aile içinde şiddete maruz kalanların \%86.2'si kadın iken, faillerin \%97.3 oranında erkek olması (Günay vd., 1999: 5) bu öngörüyü doğrulamaktadır. Ancak özellikle son zamanlarda yapılan çalışmalarda (Adak, 2013) erkeklerin de kadınların şiddetine uğradığını göstermektedir. Buna karşılık geleneksel toplumlarda erkeğin şiddete uğramasının kabul edilmezliği ve erkeğin toplumsal cinsiyet rolleri ile bunu "gurur" kapsamında değerlendirmesi (Kumar, 2012) de cinsiyete yönelik bazı soruları cevapsız bırakabilmektedir. Bu minvalde erkeklerin tartışmalarda/şiddette daha baskın olması ve bunu dışarıya aktarmak istememesine rağmen bu sonuçlar yine de teyide muhtaç olduğundan cinsiyet üzerinden bir değerlendirme yapmak doğru olmayacaktır. Ancak durumu tespit etmek amacıyla aynı aile üyeleri ile farklı zamanlarda yapılan görüşmelerde erkekler ev içi durumu "sıkıntı yok" gibi kısa bir ifade ile açıklarlarken; kadınların, sorunları sözlü dahi olsa evde sorunların arttığını beyan etmeleri bu gerçeğe işaret etmektedir.

Çalışma sürecinde dikkat çeken önemli bir veri, eşlerin dışarıda çalışmaya bağlı olarak virüsün bulaşma riskine karşı eşlerin yataklarını ayırmaları ile yeni tartışma alanlarının inşa edilmesi ve kategorik bir dışlanmanın yaşanmasıydı. Psikolojik olarak yorgun ve kaygılı hissetme, geleceği öngörememe bireyin daha stresli olmasına neden olurken, bunun kapalı mekân içerisinde "sebepsiz" tartışmalara mahal verdiği görülmektedir. Bu noktada Funda'nın (32 yaşında, kadın) evde sıkıntıların yaşanıp yaşanmadığı sorusuna verdiği cevap dikkat çekicidir; "Evet ara ara yaşadık. Eşim dışarda çalıştığı için yataklarımızı ayırdık, uyuduğumuz odaya almıyoruz. Bu da problem yarattı. Çevremden duyduğum kadarlyla bu eşler arasında baya oluyormuş. Hatta eşim birkaç gün evde kald, bir yere gitmedi ve biz bu süreçte sürekli kavga ediyorduk. Sebepsiz yere tartışıyorduk çünkü ikimizin de kafası dolu, ne olacak, bizi neler bekliyor, bir belirsizlik olduğu için sıkıntı oluyordu”. Eşlerin daha önceki dönemlerden farklı 
nedenlerle tartışmalar yaşadığını ve bunun gündelik hayatta tartışmaya neden olmayan "sebepsiz” durumlardan kaynaklandığının vurgulanması önemlidir. Benzer şekilde Emel'in (21 yaşında, kadın)anne-babası arasında gözlemlediği ve aile üyesi olarak pandemi sürecinde evdeki şiddetin veya tartışmanın artıp artmadığı sorusu üzerine, "Tabi de oluştu. En ufak bir şeyde bile tartışlyoruz. Hemen sinirleniyoruz. Bir şey söylediğimizde birbirimizi dinlememe. Insanlar birbirinden uzak olduğu zaman birbirine karşı iyi davranabiliyor. Ama uzun süre yan yana olduğu zaman birbirine karşı olan saygısını yitiriyor. Annem babam arasında uyumsuzluk arttı. Evde yaşayan herkes için geçerli bu. Her şey strese probleme neden oluyor" Bu süreçte evde kalan çocuklara yönelik Emel'in gözlemi sorulduğunda "Evin içinde oyun oynuyorlar. Bu süreçte stresleri arttı. En ufak bir sıkıntıda hemen kavga ediyorlar." Sürecin belli bir grup için değil tüm hane halkının etkilendiği bir duruma işaret ettiğini göstermektedir. Aynı durumu deneyimleyen ve gözlemleyen Ayşe, (20 yaşında, kadın) "Sürekli yan yana olduğumuz için bazen anneme bağırıyorum... Neden bağırdım sebebini bulamıyorum. Annem babamın da eskisine göre uyum problemleri oluşmaya başladı. Çocuklar daha da hırçınlaştı mesela." Ayşe'nin deneyimlediği bu süreç, Emel ile benzer bir duruma işaret etmektedir. Zira "sebesiz/nedensiz" tartışmalar sıklaşmakta iken evde kapalı kalmanın bireye vermiş olduğu stresin farklı davranışlara neden olduğunu göstermektedir. Stresin, şiddet şeklinde bir çıktı olarak somut bir görüntü kazanması sosyal öğrenme kuramının da üzerinde durduğu bir konudur (Sellers vd., 2005). Bununla beraber cinsiyet rolleri açısından düşünüldüğünde erkeğin aileye bakmakla yükümlü olduğunu düşünmesi, onun strese girmesine ve kendisini çaresiz hissetmesine, karşıdaki kişiye de şiddet uygulamasına neden olabilmektedir (Ünal, 2005). Bu bağlamda, görünürde somut bir neden yok iken eşlerin tartışması ve bunun bazen de fiziksel şiddete neden olması, bir bakıma bireyde biriken stresin dışa vurulmuş hali olarak okunabilir.

\subsection{Aile İçi Şiddetin/Tartışmanın "Sessiz ve Görünmez" Şahitleri}

Geleneksel ailelerde veya kadının ev dışında çalışmadığı durumlarda özellikle de mutfak ile ilgili konularda kadınların daha fazla söz sahibi olduğunu ya da kendisini “özgür hissettikleri” bir alan olarak öne çıkmaktadır (Kaplan, 2011: 165). Ancak pandemi sürecinde, erkekler tarafından bu tür alanlara da müdahale edilmesi doğal olarak yeni tartışmaları doğurabilmektedir. Zira görüşmeler esnasında çoğu kadın katılımcının ya babasının ya da eşinin ev/mutfak ile ilgili konulara daha fazla müdahale etmesinden şikayet ettiğini ifade etmesi bu gerçeğe işaret etmektedir. Evde kapalı kalmanın, meşguliyetin olmaması, bireylerin gün içinde aynı alanda sınırlı kalması ve birbirlerinin davranışlarını gözlemlemesi doğal olarak davranış değişikliğine neden olabilmektedir. Bu duruma bir örnek olarak Dilara'nın (23 Yaşında, Kadın) gözlemi önemlidir. “Babam normalde sakin bir yapıdadır. Genelde annem babama kızıyordu. Ama bu süreçte babam her şeye karışmaya başladı". Bu yönüyle, pandemi ile birlikte insanların sadece birbirlerine karşı tahammülleri etkilenmedi; ancak bununla beraber yeni tutumlar, yeni durumlar ve dolayısıyla yeni çatışma alanları inşa edildiği görülmektedir. Diğer bir ifade ile sınırlı alanı paylaşma zorunluluğu yeni mücadele zeminleri inşa etmektedir. Bu noktada Esma’ya (20 Yaşında, Kadın)göre “Ailemle ilgili problemler oldu tabi. Anne ve babam arasında. Rahat davranamadıklarından dolayı mesela dışarı çıkamamaları babamda agresifliğe neden oldu. Sinirleniyor durup dururken. Bu da annem babam arasında sözlü tartışmaya neden oluyor. Babam bazen bize karşı da sinirleniyor”. Ebeveynler arasında sorunların yaşanması, kapalı ve sınırlı bir mekanın varlığı ile doğrudan ilişkilendirilirken, sinirlenme, agresif tutumlar bunun çıktısı olarak gündelik hayatı ve ilişkileri etkilemektedir. Vahib'e (2002: 317) göre ailenin bir üyesi olarak ebeveynler arasındaki tartışmalara/şiddete tanıklık eden kişilerin "sessiz", "unutulmuş" ya da "görünmez" tanıklar olarak tanımlanmalarına neden olurken, etkilenmenin çok daha görünür ve ileriki yaşlarda bu kişilerde somut şiddet durumları bulmak daha yaygın olabilmektedir. Evdeki çocukların bu tür durumlara şahit olması, daha geniş çalışmaların konusu olmakla beraber sonraki süreçte önemli etkileri olacağını ifade etmek mümkündür. Nitekim şiddete tanık olan çocukların ileriki dönemlerde kendi aile bireylerine şiddet uygulama ihtimali artarken, özellikle erkeklerin rol model olarak şiddet uygulayan babayı örnek almaları (Ünal, 2005) şiddetin kronik bir hal almasına neden olmaktadır.

Davranışlarda değişimler, stres, kaygı ve bunların gündelik hayata yansıması ile oluşan yeni gerginlikler bireylerin davranışlarında bazı sorunların ve anormalliklerin yaşanmasına neden olduğu görülmektedir. Örneğin bir üniversite öğrencisi olarak Dilara'ya (23 yaşında, kadın) evde kalış sürecinin kendisini nasıl etkilediği sorulduğunda "Psikolojim bozuldu bu süreçte. Sürekli bir şeyler düşünüyorum, bir takıntı halindeyim. Ödevlerimi yaparken, o an yapmam lazım yapamayınca da elim ayağım titriyor sinirleniyorum. Takıntılarım oluştu. Bir şey yamuk olduğunda gidip düzeltiyorum hemen. Her şey ilgimi çekiyor". Takıntılı davranışlar, stres ve kaygı kapalı mekânda üretilen önemli ruh halleridir. Ancak burada dikkat edilmesi gereken diğer bir nokta, ilgi alanlarının değişimi ve Dilara’nın vurguladığı üzere daha önce dikkat çekmeyen durumların dahi ilgi alanına girmesi, insanların meşguliyet aradığının bir göstergesi olarak karşımıza çıkmaktadır. Daha önce kaldığı yeri değiştiren ve ablasıeniştesinin evinde kalan Kadriye'ye (20 yaşında, kadın) bu süreçte beraber yaşadığ kişilerle yaşadığı sorun olup olmadığ sorulduğunda "Yaşıyorum tabii, ben ailemle kalmıyorum şuan ablamlarla kallyorum. Eniştemle ve ablamla bu süreçte dışarı çıkamamamdan dolayı bunlarla çok tartışmaya başladım. Daha önce böyle sorunlar yaşamıyordum ve tamamıyla pandemi sürecinde başlayan sıkıntılar... Onlardan uzaklaşmak istiyorum ve bundan dolayı sürekli tartışlyoruz. Birbirimize bağırıp çağırıyoruz. Onlarda bu süreçte kendi aralarında sıkıntı yaşıyorlar. Bazen fiziksel şiddete kadar varabiliyor." Kadriye'nin kendi yaşı itibariyle ve daha önceki uğraşları dikkate alındığında dış dünya ile irtibatının yüksek olduğu tahmin edilebilir. Beraber kaldığı kişilerle "sözlü tartışma” boyutunda sorunlar yaşaması kendi içinde önemli iken onu gözlemci konumuna getiren boyutun daha dikkat çekici olduğunu aktarmak gerekir. Diğer bir ifade ile Kadriye'nin eniştesi ve ablası ile sorunlar yaşadığını ifade ettikten sonra eniştesi ve ablası arasında sorunların yaşandığını ve bunun fiziksel şiddete vardığını aktarması oldukça önemli bir veridir. Zira kendisi de sorun yaşarken ve bunu kapalı mekanın bir çıktısı olarak sunarken aynı şekilde aile ilişkilerini gözleme noktasında onun bunlara şahit olması da psikolojik olarak olumsuz etkilenmeye işaret etmektedir.

Covid-19 pandemisinin aile içi ilişkileri etkilemesinin yanında toplumu ekonomik olarak zor durumda bırakması da sürecin önemli bir boyutuna işaret etmektedir. Bu noktada görüşme esnasında ekonomik durumlar ile ilgili doğrudan sorular 
bulunmazken bunun insanların gündelik hayatını olumsuz etkilediği dolaylı olarak aktarılmaktadır. Nitekim bireylerin daha önce alabildiklerini alamaması, temel ihtiyaçlara ulaşmada sıkıntılar yaşaması pandemi ile beraber gündelik hayatın değişimine işaret etmektedir. Örneğin bu noktada Remziye (22 yaşında, kadın)“Bende bu süreçte uyum sorunu yaşlyorum. ev de oturuyorsun, ne yapacă̆ını bilmiyorsun, ailede bir gelir yok, istediğini temin edemiyorsun. Bu ister istemez iletişim sorununu ailede ve bende yarattı. Ya küçük bir durumu bile büyütebiliyoruz. Tartışmalar tabi şiddete varmadan bitiyor." Remziye'nin diğer katılımcılardan farklı olarak küçük sorunların büyütülmesine ek olarak "iletişim” sorunlarına dikkat çekmesi ayrıca vurgulanması gereken önemli bir veridir. Nitekim, aile içi ilişkilerde iletişim probleminin olması sonraki dönemde daha ciddi sonuçlar doğurabilmektedir. Aile içi şiddet çocuklar açısından değerlendirildiğinde çocuğun kişilik gelişimi bakımından ciddi sonuçlar ortaya çıkarabilirken, ayrıca eşlerde de benlik saygısı ile ilgili problemlere ve birbirlerine karşı dürüst tavır geliştirememelerine neden olmaktadır (Şahin \& Aral, 2012: 64). Bu yönüyle, aile içi ilişkilerde yaşanan tartışma/şiddet durumları tek boyutlu olmayıp, kurumsal olarak aile ve aile üyeleri üzerinde psikolojik olarak olumsuz sonuçlar doğurabilmektedir.

\section{SONUC}

Afet dönemlerinde, bireylerin günümüzde Covid-19 pandemisinin neden olduğu gibi aynı mekânı paylaşma, sınırlı ekonomik ve sosyal imkanı birlikte kullanma/paylaşma, ev içi davranışların kontrolü, sağlık sorunları ile başa çıkma, dışarıdan gelen sosyal ve psikolojik desteğin azalması ya da bitmesi sonucu meydana gelen ruhsal bozukluklar (Rezaeian, 2013,1104) kamusal ve bürokratik ilişkilerin kısıtlanması (Lu, 2004) gibi durumlar bireylerin aile içinde şiddete bazen de ölme/öldürülme varan tartışmalar yaşamlarına neden olabilmektedir. Nitekim bu çalışmanın verileri dikkate alındığında, aile içi ilişkilerde bireylerin yaşadıkları psikolojik sorunlardan kaynaklı olarak "nedensiz/sebepsiz” tartışmalar yaşadığı görülmektedir. Sokağa çıkma yasaklarının olduğu dönemde aile üyelerinin aynı mekanı paylaşmaları ve davranışların gözetim altında tutulması ev içi tartışmanın/şiddetin önemli bir nedenini oluştururken, hastalığa yakalanma korkusu, kurumsal işleyişin sekteye uğraması da yaşanan olumsuzluklara neden olabilmektedir. Aile bireylerinden her birinin yaşanan bu durumları kendi özelinde deneyimlemesi ve özellikle çocukların sonraki süreçte aileye yönelik tutumlarını etkilerken, yaşan tartışmanın/şiddetin etkisi daha iyi analiz edilecektir.

Afetlerin önemli ayırt edici bir özelliği, birey üstü ve toplumları sadece fiziksel ve ekonomik değil psikolojik olarak da etkilemesidir. Özellikle afet sonrasında bireylerin kaygı, endişe ve depresyon durumları olumsuz yönde etkilenirken, bunun aile içi ilişkilere yansıması da menfi bir boyut sergilemektedir. Bu anlamda afeti deneyimleyen kişilere ek olarak, bu sürece tanık olan kişilerde de benzer sonuçların ortaya çıkması afetlerin bireysel olduğu kadar toplumsal boyutuna da işaret etmektedir. Bununla beraber pandemi sürecinde aile içi tartışma/şiddet ile ilgili yeni alışkanlıkların ve önceliklerin de ortaya çıkması önemlidir. Nitekim yapılan görüşmelerin neredeyse tamamında katılımcıların Covid-19 hastalığına yakalanmamak için hastaneyi tercih etmediklerini vurguladıkları görülmektedir. Bu noktada, aile içi şiddetin dahi bu eksende ele alınabildiğini görmek gerekir. Zira virüse yakalanma kaygısı bireyin hastaneye gitmesini önlerken, maruz kalınan şiddetin önemsiz kılınmasına neden olabilmektedir. Bu minvalde Godin'in (2020) aktardığı bilgiler doğrultusunda düşünüldüğünde, özellikle kronik hastalığ1 bulunanların ve virüse daha "dayanıksız" olduğunu düşünen kişilerin hayatlarında yeni öncelikler listesini çıkarması kayda de ğer bir veridir. $\mathrm{Bu}$ çalışma verilerine de yansıdığı şekilde, insanlar hastane ortamında pandemiye yakalanma ihtimaline karşın özellikle alternatif ve bitkisel ilaçlar ile hastalıklarını tedavi yoluna gittikleri görülmektedir. Yine çalışma bulgularının hastane gibi devlet kurumlarının kısmi olarak da olsa faaliyetlerine ara vermesi bireysel ev içi ilişkilerde ortaya çıkan tartışma ve şiddetin sıradanlaşmasına ve şikâyeti önleyebilmektedir. Ancak kişilerin evde kullandıkları ilaçların beklenen sonucu vermemesi ve hastaneye gidememe, kişileri stres ile baş başa bırakırken bunun çevredeki kişilere yansıması da gerçekleşebilmektedir.

\section{KAYNAKÇA}

Adak, N. (2013). Madalyonun Öteki Yüzü: Erkeğe Yönelik Şiddet. Sosyoloji Araştırmaları Dergisi, 16 (2), 1-28. Do1: $10.18490 /$ Sosars. 136095

Adams, P. \& Adams, G. (1984) Mount Saint Helens's Ashfall: Evidence for A Disaster Stress Reaction, American Psychologist. 39, 252-260. Doi:10.1037//0003-066x.39.3.252

Allen-Ebrahimian, Bethany (2020). China’s Domestic Violence Epidemic, Axios, (7). Https://Www.Axios.Com/ChinaDomestic-Violence-Coronavirus-Quarantine-7b00c3ba-35bc-4d16-Afdd-B76ecfb28882.Html.

Beck, U. (1992). Risk Society: Towards A New Modernity, London: Sage Publications.

Benedek, D., Fullerton C. \& Ursano R. (2007). First Responders: Mental Health Consequences of Natural and Human-Made Disasters for Public Health and Public Safety Workers. Annu Rev Public Health. 28, 55-68.

Biswas, A., Rahman, A., Mashreky, S., Rahman, F., \& Dalal, K. (2010). Unintentional Injuries and Parental Violence Against Children During Flood: A Study in Rural Bangladesh. Rural And Remote Health, 10(1), 1199.

Campbell, A. M., Hicks, R. A., Thompson, S. L., \& Wiehe, S. E. (2020). Characteristics of Intimate Partner Violence Incidents and the Environments in Which They Occur: Victim Reports to Responding Law Enforcement Officers. Journal of Interpersonal Violence, 35(13-14), 2583-2606. https://doi.org/10.1177/0886260517704230

Campbell, A., M. (2020). An Increasing Risk of Family Violence During the Covid-19 Pandemic: Strengthening Community Collaborations to Save Lives. Forensic Science International: Reports. 1-5. Http://Doi.Org/10.1016/J.Fsir.2020.100089 
Closson, K., Lee, M., Gibbs, A., \& Kaida, A. (2020). When Home is Not a Safe Place: Impacts of Social Distancing Directives On Women Living with Hiv. AIDS and Behavior, 1-3. Advance Online Publication. Https://Doi.Org/10.1007/S10461020-02941-Y

Coulthard, P., Hutchison,L. Bell, J. A., I. D.Coulthard, \& Kennedy, H. (2020). Covid-19, Domestic Violence and Abuse, And Urgent. Britısh Dental Journal. 228 (12). 923-926

Dayton-Johnson, J. (2006). Natural Disaster and Vulnerability. OECD Development Centre Policy Brief No. 29.

Fisher, S. (2010). Violence Against Women and Natural Disasters: Findings from Post-Tsunami Sri Lanka. Violence Against Women, 16(8), 902-918. Https://Doi.Org/10.1177/1077801210377649

Gearhart, S., Perez-Patron, M., Hammond, T. A., Goldberg, D. W., Klein, A., \& Horney, J. A. (2018). The Impact of Natural Disasters On Domestic Violence: An Analysis of Reports of Simple Assault in Florida (1999-2007). Violence and Gender, 5(2), 87-92. Https://Doi.Org/10.1089/Vio.2017.0077

Godin, M. (2020) As Cities Around The World Go On Lockdown, Victims Of Domestic Violence Look For A Way Out, Time, March 18, 2020, Https://Time.Com/5803887/Coronavirus-Domestic-Violence-Victims/.

Günay Y, Çınar T, \& Keskin R. (1999) Ölümle Sonuçlanmayan Etkili Eylem Olgularının Sosyal Yönden Değerlendirilmesi. Adli Tıp Bülteni. 4(1), 5-11.

İnce, C. (2020a). Afetler çağ1, afetlerin yapısal dönüşümü ve COVID-19. Turkish Studies, 15(4), 565-578. https://dx.doi.org/10.7827/TurkishStudies.44080.

İnce, C. (2020b). Afetlerde Sosyal Savunmasız Bir Grup Olarak Yaşlılar: Covıd-19 Örneği. Avrasya Sosyal ve Ekonomi Araştırmaları Dergisi, 7 (9), 184-198. Retrieved from https://dergipark.org.tr/tr/pub/asead/issue/56911/791042.

Kanaisty K, \& Norris F.H. (1995). Mobilization and Deterioration of Social Support Following Natural Disasters. Curr Dir Psychol Sci. 4, 94-98.

Kaplan, M. (2011). “Kaplumbağa’nın Özgürlüğü”: Kadınlar Ve Ev İçi Emek. Folklor/Edebiyat, 17(65), 163-172.

Keenan H. T, Marshall S. W., Nocera M. A., \& Runyan D. K. (2004). Increased Incidence of Inflicted Traumatic Brain Injury in Children After a Natural Disaster. Am J Prev Med. 26(3),189-193. Doi:10.1016/J.Amepre.2003.10.023

Kılıç, E. (2018). Aile Ve Din Bağlamında Kur'an'da Mahremiyet Tasavvuru". Journal Of Analytic Divinity 2 (1): 54-81 . Https://Doi.Org/10.46595/Jad.375144

Kumar, A. (2012). Domestic Violence Against Men in India: A Perspective, Journal of Human Behavior in The Social Environment, 22, 290-296,

Kurt, E., \& Gülbahçe, A. (2019). Van Depremini Yaşayan Öğrencilerin Travma Sonrası Stres Bozukluğu Düzeylerinin İncelenmesi. Atatürk Üniversitesi Sosyal Bilimler Enstitüsü Dergisi,23 (3), 957-972.

Liem, M. \& Reichelmann, A. (2013). Patterns of Multiple Family Homicide, Homicide Studies. 18 (1), 44-58.

Loayza, Norman V., Eduardo O., Jamele R., \& Luc C. 2012. Natural Disasters and Growth: Going Beyond the Averages, World Development, 40 (7), 1317-36

Lu T.H. (2004) Earthquake and Suicide: Bringing Context Back into Disaster Epidemiological Studies. Int J Epidemiol, 33, 1406-9.

Mustafa D. (1998). Structural Causes of Vulnerability to Flood Hazard in Pakistan. Econ Geogr. 74, $289-305$.

NDVH (National Domestic Violence Hotline) (2020), Staying Safe During Cov1d-19, National Domestic Violence Hotline, March 13, Https://Www.Thehotline.Org/2020/03/13/Staying-Safe-During-Covid-19/

Ochs, H. A., Neuenschwander C. \& Dodson T B. (1996). Are Head, Neck and Facial Injuries Markers of Domestic Violence?, The Journal of the American Dental Association. 127, 757-761.

Özkiraz A. \& İşçibaş G. (2006) Osmanlı'dan Günümüze Türk Toplumunda Aile Yapısı Ve Boşanma. KMÜ Sosyal Ve Ekonomik Araştırmalar Dergisi, 18(30), 88-95.

Perry, R. W. (2007) What Is a Disaster? İçinde Handbook of Disaster Research, 1-15. (Ed. H. Rodriguez, E. L. Quarantell Ve R.R. Dyness) Handbooks of Sociology and Social Research. (Springer Science + Business Media, Llc).

Phillips, M. K., Cinderich, A. B., Burrell, J. L., Ruper, J. L., Will, R. G. \& Sheridan, S. C. (2015). The Effect of Climate Change On Natural Disasters: A College Student Perspective. Weather, Climate \& Society, 7(1), 60-68.

Doi:10.1175/Wcas-D-13-00038.1.

Rezaeian, M. (2013). The Association Between Natural Disasters and Violence: A Systematic Review Of The Literature And A Call For More Epidemiological Studies. Journal of Research in Medical Sciences, 18(12), 1103-1107. 
Roth, F., Eriksen, C., \& Prior, T., 2017. Understanding The Root Causes of Natural Disasters. The Conversation 27 June. Https://Theconversation.Com/Understanding-The-Rootcauses-Of-Natural-Disasters-80017

Sabuncuoğlu, O.; Çevikaslan, A. \& Berkem, M. (2003). Marmara Depreminden Etkilenen İki Ayrı Bölgede Ergenlerde Depresyon, Kayg1 Ve Davranış. Klinik Psikiyatri, 6, 189-197.

Sellers, C. S., Cochran, J. K., \& Branch, K. A. (2005). Social Learningtheory and Courtship Violence: A Research Note. Deviant Behavior, 26,379-395

Schumacher, J. A., Coffey, S. F., Norris, F. H., Tracy, M., Clements, K., \& Galea, S. (2010). Intimate Partner Violence and Hurricane Katrina: Predictors and Associated Mental Health Outcomes. Violence and Victims, 25(5), $588-603$. Https://Doi.Org/10.1891/0886-6708.25.5.588

Smith, S., Fowler, K. \& Niolon, P. (2014) Intimate Partner Homicide and Corollary Victims in 16 States: National Violent Death Reporting System, 2003-2009, Am. J. Public Health, 104, 461-466.

Stewart, D. E. \& Robinson, G. E. (1998). A Review of Domestic Violence and Women's Mental Health. Archives of Women's Mental Health, 1, 83-89.

Şahin, S. \& Aral, N. (2012).Aile İçi İletişim. Ankara Sağlık Bilimleri Dergisi, 1(3), 55-56.

Tanhan F, \& Kardaş F. (2014). Van Depremini Yaşayan Ortaöğretim Öğrencilerinin Travmadan Etkilenme Ve Umutsuzluk Düzeylerinin İncelenmesi. Sakarya University Journal of Education, (4), 102-115.

Ünal, G. (2005). Aile İçi Şiddet. Aile Ve Toplum. (7)2. Https://Dergipark.Org.Tr/En/Download/Article-File/198147

Vahip, I. (2002). Evdeki Şiddet Ve Gelişimsel Boyutu: Farklı Bir Açıdan Bakış. Türk Psikiyatri Dergisi. 2002; 13(4), 312-319

Vehid H., Alyanak B. \& Eksi A. (2006) Suicide Ideation After The 1999 Earthquake in Marmara, Turkey. Tohoku J Exp Med; (208), 19-24

World Health Organization. (2020). Covı-19 And Violence Against Women: What The Health Sector/System Can Do. Who, 26 March2020. Https://Apps.Who.İnt/İris/Bitstream/Handle/10665/331699/Who-Srh-20.04-Eng.Pdf

Yıldırım, A. (1998). Sıradan Şiddet: Kadına Ve Çocuğa Yönelik Şiddetin Toplumsal Kaynakları. İstanbul: Boyut Kitapları.

NPR (2020). Some Stock Up On Guns And Ammunition During Coronavirus Crisis, 21 06, 2021 tarihinde https://www.npr.org/2020/03/20/817369503/some-stock-up-on-guns-and-ammunition-during-coronavirus-crisis adresinden alınd. 